\title{
STRATEGI PENINGKATAN PRODUKTIVITAS KOPI ROBUSTA DI DESA SIGODANG BARAT KECAMATAN PANEI KABUPATEN SIMALUNGUN PROVINSI SUMATERA UTARA
}

\section{Strategy of Enhancing Robusta Coffee Productivity in Sigodang Barat Village Panei Sub-district Simalungun Regency}

\author{
Jef Rudiantho Saragih ${ }^{1)}$ \\ ${ }^{1)}$ Program Studi Agribisnis Fakultas Pertanian Universitas Simalungun \\ Jl. Sisingamangaraja Pematangsiantar 21139 Sumatera Utara \\ Email: jefsaragih@ymail.com
}

Submit: 5 Juli 2020, Revised: 6 Agustus 2020, Accepted: Agustus 2020

\begin{abstract}
The main problem faced by Robusta coffee farmers is its low productivity compared to its potential that can be achieved through good farm management. This study aims to determine the Robusta coffee productivity performance and to find new strategies to increase robusta coffee productivity at the farm level in West Sigodang village, Panei sub-district, Simalungun Regency, North Sumatera in the period of February to March 2019. Farmer respondents were randomly selected while other respondents included an extension worker, a Plantation Service staff, six Pangulu Nagori, a village head, a collecting trader, and a production equipment trader. Primary and secondary data were processed using Revenue-Cost Ratio (R/C) analysis and SWOT Analysis. Robusta coffee productivity in the study area is 1.275 ton/ha, with $\mathrm{R} / \mathrm{C}$ value of 2.67 . The strategies to increase the Robusta coffee farm productivity are through: (1) using suitable land and varieties; (2) exploiting the experience of farmers and the lenience of farm management; (3) utilizing local materials; and (4) integrating internal strengths to improve product quality. Local government through its related technical services are expected to play more attention to the farmers and provide good services through the provision of training and technical extension to improve the management of the Robusta coffee farming.
\end{abstract}

Keywords: Productivity; Robusta coffee; Simalungun and SWOT Analysis.

\begin{abstract}
ABSTRAK
Permasalahan utama yang dihadapi petani adalah produktivitas kopi robusta masih rendah dibandingkan dengan potensi produktivitas yang dapat dicapai melalui manajemen usahatani yang baik. Penelitian ini bertujuan untuk mengetahui kinerja produktivitas kopi robusta dan mencari strategi baru untuk meningkatkan produktivitas kopi robusta di tingkat petani. Penelitian dilaksanakan di Nagori (Desa) Sigodang Barat, KecamatanPanei, Kabupaten Simalungun, pada bulan Februari-Maret 2019. Responden penelitian terdiri dari
\end{abstract}


petani kopi robusta yang dipilih secara acak sederhana (65 orang), PPL (1 orang), pedagang pengumpul (1 orang), pedagang sarana produksi (1 orang), pegawai Dinas Perkebunan (1 orang), dan (6) Pangulu Nagori/Kepala Desa (1 orang). Data primer dan sekunder diolah dengan menggunakan analisis Revenue-Cost Rasio (R/C) dan Analisis SWOT. Produktivitas kopi robusta di daerah penelitian adalah 1,275 ton/ha, dengan nilai R/C sebesar 2,67. Strategi peningkatan produktivitas usahatani kopi robusta berada pada Kuadran 2 (Strategi Diversifikasi). Strategi yang sesuai untuk digunakan adalah Strategi ST melalui: (1) Penggunaan lahan dan varietas yang sesuai untuk meminimalkan konversi kopi robusta ketanaman kopi arabika atau tanaman lainnya; (2) Mendayagunakan pengalaman petani dan kemudahan manajemen usahatani dalam menyikapi kurangnya penyuluhan dan pelatihan yang tersedia; (3) Memanfaatkan bahan-bahan lokal sebagai sarana produksi berbasis pengalaman, biaya murah, dan manajemen usahatani yang fleksibel; dan (4) Memadukan kekuatan internal untuk meningkatkan kualitas produk untuk meningkatkan posisi tawar dalam harga jual. Pemerintah daerah melalui dinas teknis terkait diharapkan lebih memperhatikan petani dan memberikan pelayanan yang baik melalui pengadaan pelatihan dan penyuluhan teknis untuk memperbaiki manajemen usahatani kopi robusta di daerah penelitian.

Kata Kunci: Produktivitas; Kopi Robusta; Analisis SWOT dan Simalungun.

\section{PENDAHULUAN}

Dalam perdagangan dunia, komoditas kopi merupakan produk ekspor terpenting kedua, setelah minyak bumi (Gregory dan Featherstone, 2008; ICO, 2010; Amsalu dan Ludi, 2010). Sebagai komoditas pertanian yang diperdagangkan paling luas, sebagian besar kopi di dunia dikelola dalam skala kecil dengan peran perempuan yang signifikan (ITC, 2011). Kopi diproduksi lebih dari 70 negara sedang berkembang dan 45 negara diantaranya menghasilkan $97 \%$ produksi kopi dunia. (Batista et al., 2020; Naegele, 2020).

Di tingkat global, pada tahun 2018/2019, Indonesia merupakan negara produsen kopi keempat setelah Brazil, Vietnam, dan Kolombia. Data International Coffee Organization (ICO, 2019) menunjukkan bahwa total produksi kopi Indonesia pada tahun 2018/2019 mencapai 565 ton. Tren produksi kopi Indonesia mengalami penurunan dalam 10 tahun terakhir. Pada tahun 2012/2013, Indonesia masih menempati posisi ketiga dalam total produksi. Sementara itu, pada tahun 2018/2019, produksi Brazil mencapai 3.775 ton, produksi Vietnam 1.870 ton, dan produksi Kolombia 831 ton.
Direktorat Jenderal Perkebunan Kementerian Pertanian RI (2017), merilis data produktivitas kopi robusta tahun 2016 di Indonesia hanya sekitar $522 \mathrm{~kg} / /$ ha/tahun. Produktivitas kopi robusta di Provinsi Sumatera Utara sedikit lebih tinggi dari tingkat nasional yaitu $575 \mathrm{~kg} / \mathrm{ha} /$ tahun dengan jumlah petani sebanyak 32.510 KK. Kondisi yang lebih baik ditemukan di Kabupaten Simalungun dimana produktivitas kopi robusta dapat mencapai 1.359 $\mathrm{kg} / \mathrm{ha} /$ tahun, dengan jumlah petani 3.205 KK.

Permasalahan utama yang ditemukan berdasarkan data di atas adalah bahwa produktivitas kopi robusta masih rendah dibandingkan dengan potensi produktivitas yang dapat dicapai melalui manajemen usahatani yang baik, yaitu dapat mencapai $2.000-2.500 \mathrm{~kg} / \mathrm{ha} / \mathrm{tahun}$.

Produktivitas pertanian merupakan konsep teknis yang menggambarkan kemampuan untuk menghasilkan produksi atau daya produksi tanaman berdasarkan faktor-faktor pendukung alami, faktor genetis tanaman itu sendiri, dan faktor buatan manusia. (Abman and Carney, 2020; Kapri and Ghimire, 2020; RiveraPadilla, 2020).

Hasil penelitian Sunanto et al. (2019) menemukan bahwa penyuluhan/ 
pelatihan yang intensif dan penyebaran informasi teknologi produksi berperan penting dalam peningkatan produktivitas kopi arabika di Kabupaten Toraja Utara. Mahfud et al. (2010) menyatakan bahwa kerusakan tanaman oleh penyakit karat daun dapat diturunkan $60 \%$, serta produktivitas ditingkatkan $89,5 \%$ melalui kinerja teknologi produksi yang direkomendasikan. Pada akhirnya dapat meningkatkan pendapatan usahatani sebesar $120 \%$. Beberapa permasalahan teknis dan sosial terkait dengan mutu dan produktivitas kopi robusta di Nusa Tenggara Barat terutama adalah kurang baiknya manajemen usahatani, terbatasnya akses petani atas, tenaga kerja, dan teknologi (Aklimawati et al., 2014).

Strategi adalah suatu rencana yang memadukan sasaran, kebijakan, dan tindakan kedalam suatu kesatuan yang terpadu (Mintzberg dan Quinn, 1991). Pemilihan strategi yang baik memerlukan data yang akurat yang dapat dikumpulkan lewat variabel-variabel yang dinamis. Proses perumusan dan pemilihan strategi dimulai dengan melakukan perbandingan data yang digali, analisis faktor internal dan eksternal, serta mengidentifikasi alternatif strategi yang layak untuk diterapkan (Glueck dan Jauch, 1994).

Analisis SWOT merupakan analisis kekuatan, kelemahan, peluang, dan ancaman (Strengths, Weakness, Opportunities, dan Threats). (Thamrin and Pamungkas, 2017; Quezada et al., 2019). Analisis SWOT merupakan identifikasi yang bersifat sistematis dari faktorfaktor kekuatan dan kelemahan organisasi serta peluang dan ancaman lingkungan luar dan strategi yang menyajikan kombinasi terbaik diantara keempatnya. Setelah diketahui kekuatan, kelemahan, peluang, dan ancaman, barulah suatu institusi dapat menentukan strategi dengan memanfaatkan kekuatan yang dimilikinya untuk mengambil keuntungan dari peluangpeluang yang ada, sekaligus memperkecil atau bahkan mengatasi kelemahan yang dimilikinya untuk menghindari ancaman yang ada.

\begin{abstract}
Berdasarkan penjelasan di atas, penelitian ini bertujuan untuk mengidentifikasi kinerja produktivitas kopi robusta di Kabupaten Simalungun dan daerah penelitian, serta mencari strategi baru dalam upaya meningkatkan produktivitas kopi robusta di tingkat petani.
\end{abstract}

\section{METODE PENELITIAN}

Kabupaten Simalungun dipilih sebagai lokasi penelitian atas pertimbangan karena masyarakatnya sebagian besar membudidayakan tanaman kopi robusta. Penelitian ini dilaksanakan pada bulan Februari-Maret 2019. Metode penentuan responden dilakukan dengan metode gabungan yaitu acak sederhana dan sampel purposif yang terdiri dari: (1) petani kopi robusta 65 orang; (2) Penyuluh Pertanian Lapangan (PPL) 1 orang; (3) pedagang pengumpul 1 orang; (4) pedagang sarana produksi 1 orang; (5) pegawai pada Dinas Perkebunan Kabupaten Simalungun 1 orang; dan (6) Pangulu Nagori (Kepala Desa) 1 orang.

Jenis data yang digunakan dalam penelitian ini adalah data primer dan data sekunder. Data primer diperoleh melalui wawancara dengan petani dan stakeholder kopi robusta di tingkat desa. Data sekunder merupakan data pendukung yang diperoleh dari Badan Pusat Statistik Kabupaten Simalungun, Ditjen Perkebunan, ICO, dan sumber lain yang relevan. Data dianalisis secara deskriptif, analisis R/C, dan Analisis SWOT.

Matrik SWOT menggambarkan faktor internal (kekuatan dan kelemahan) serta faktor eksternal (peluang dan ancaman). Masing-masing faktor diidentifikasi lima faktor terpenting untuk menentukan empat set kemungkinan alternatif strategis setelah dilakukan rating dan pembobotan dan rating terbobot dan difigurasi pada diagram Cartesius untuk menemukan fokus strategi untuk meningkatkan produktivitas kopi robusta di daerah penelitian (Tabel 1). 
Tabel 1. Matriks Alternatif Strategi

\begin{tabular}{|c|c|c|}
\hline EFAS & $\begin{array}{l}\text { Kekuatan (S): } \\
\text { Identifikasi } 5 \\
\text { faktor kekuatan } \\
\text { internal } \\
\text { terpenting }\end{array}$ & $\begin{array}{l}\text { Kelemahan } \\
(\mathrm{W}) \text { : } \\
\text { Identifikasi } 5 \\
\text { faktor } \\
\text { kelemahan } \\
\text { internal } \\
\text { terpenting }\end{array}$ \\
\hline $\begin{array}{l}\text { Peluang }(\mathrm{O}) \text { : } \\
\text { Identifikasi } 5 \\
\text { faktor peluang } \\
\text { eksternal } \\
\text { terpenting }\end{array}$ & $\begin{array}{l}\text { Strategi SO: } \\
\text { Merumuskan } \\
\text { strategi yang } \\
\text { menggunakan } \\
\text { kekuatan untuk } \\
\text { memanfaatkan } \\
\text { peluang }\end{array}$ & $\begin{array}{l}\text { Strategi WO: } \\
\text { Merumuskan } \\
\text { strategi yang } \\
\text { meminimalkan } \\
\text { kelemahan } \\
\text { untuk } \\
\text { memanfaatkan } \\
\text { peluang }\end{array}$ \\
\hline $\begin{array}{l}\text { Ancaman }(\mathrm{T}) \text { : } \\
\text { Identifikasi } 5 \\
\text { faktor ancaman } \\
\text { eksternal } \\
\text { terpenting }\end{array}$ & $\begin{array}{l}\text { Strategi ST: } \\
\text { Merumuskan } \\
\text { strategi yang } \\
\text { menggunakan } \\
\text { kekuatan untuk } \\
\text { mengatasi } \\
\text { ancaman }\end{array}$ & $\begin{array}{l}\text { Strategi WT: } \\
\text { Merumuskan } \\
\text { strategi yang } \\
\text { meminimalkan } \\
\text { kelemahan dan } \\
\text { menghindari } \\
\text { ancaman }\end{array}$ \\
\hline
\end{tabular}

Faktor internal dan eksternal diberi rating mulai dari 4 untuk kategori sangat baik sampai 1 untuk kategori tidak baik. Tahapan yang dilakukan dalam menentukan strategi peningkatan produktivitas adalah mengidentifikasi factor kekuatan dan kelemahan serta faktor peluang dan ancaman. Kemudian diberi rating 1 sampai 4 berdasarkan pentingnya faktor sebagaimana dijawab responden atas kuesioner yang diberikan. Kemudian masing-masing faktor inernal dan eksternal diberikan bobot berdasarkan urutan penting faktor yang ada dengan jumlah bobot sama dengan 1 untuk masing-masing faktor internal dan faktor eksternal.

Selanjutnya dihitung perkalian rating dan bobot untuk masing-masing faktor untuk pada akhirnya dihitung selisihnya untuk faktor internal dan eksternal. Selisih kedua faktor ini digambarkan (diplot) pada diagram Cartesius untuk menentukan pemilihan strategi yang sesuai untuk peningkatan produktivitas kopi arabika di daerah penelitian. Tahapan Analisis SWOT yang digunakan dalam penelitian ini mengacu pada hasil penelitian sebelumnya, yaitu Habibi et al. (2019), Saragih (2018), Laili dan Diartho (2018), Heryanto dan Ramadhoni (2018), serta Murdani dan Koswara (2018).

\section{HASIL DAN PEMBAHASAN}

Rasio Penerimaan dan Biaya. Produksi, penerimaan, pengeluaran, dan Rasio Penerimaan dan Biaya (R/C) usahatani kopi Robusta di Nagori Sigodang Barat Kecamatan Panei Kabupaten Simalungun disajikan pada Tabel 2.

Tabel 2. Kinerja Usahatani Kopi Robusta

\begin{tabular}{|l|r|r|}
\hline Kinerja & Setiap Usahatani & \multicolumn{1}{|c|}{ Setiap Hektar } \\
\hline Luas lahan (ha) & 0,65 & 1,00 \\
\hline Produksi (kg/tahun) & 829 & 1.275 \\
\hline Harga (Rp/kg) & 23.000 & 23.000 \\
\hline Penerimaan (Rp/tahun) & 19.067 .000 & 29.333 .846 \\
\hline Biaya produksi (Rp/tahun) & 7.136 .162 & 10.978 .711 \\
-Tenaga kerja (Rp/tahun) & 3.946 .000 & 6.070 .769 \\
-Sarana produksi (Rp/tahun) & 3.054 .000 & 4.698 .462 \\
-Penyusutan alat (Rp/tahun) & 87.162 & 134.095 \\
-Pajak Lahan (Rp/tahun) & 49.000 & 75.385 \\
\hline Pendapatan (Rp/tahun) & 11.930 .838 & 18.355 .135 \\
\hline R/C & 2,67 & 2,67 \\
\hline
\end{tabular}


Berdasarkan Tabel 2, produksi ratarata kopi robusta pada luas lahan 0,65 ha adalah $829 \mathrm{~kg} / \mathrm{ha} /$ tahun. Dengan data tersebut, maka produktivitas kopi arabika di daerah penelitian adalah 1,275 ton/ha/tahun. Produktivitas ini masih lebih rendah dari potensi produksi yang dapat dicapai yaitu 2,5 ton/ha/tahun. Kinerja produktivitas tersebut dikaitkan dengan harga dan biaya produksi, maka rasio penerimaan dan biaya usahatani kopi robusta di daerah penelitian dapat mencapai 2,67.

Produktivitas kopi robusta pada penelitian ini sedikit lebih rendah dari produktivitas usahatani kopi robusta di Kecamatan Panti Kabupaten Jember yaitu sebesar 1,330 ton/ha untuk kopi robusta, dengan pendapatan usahatani kopi robusta Rp13.276.003/ha/tahun (Abimanyu et al., 2018). Sementara nilai $R / C$ dalam penelitian ini lebih tinggi dari nilai $\mathrm{R} / \mathrm{C}$ usahatani kopi robusta di Kabupaten Rejang Lebong, Bengkulu yaitu 1,87, dengan tingkat pendapatan Rp8.417.600/ha/tahun (Listyati et al., 2017).

Analisis SWOT. Berdasarkan Tabel 3 dan Tabel 4 diperoleh selisih kekuatan dan kelemahan sebesar 0,70. Hal ini berarti, kekuatan internal masih lebih tinggi meskipun terdapat beberapa kelemahan. Sementara itu, selisih antara peluang dan ancaman diperoleh sebesar -0.40. Hal ini berarti bahwa ancaman untuk peningkatan produktivitas kopi robusta cukup besar dibandingkan dengan peluang yang ada.

Selisih antara kekuatan dan kelemahan, dan dibandingkan dengan selisih antara peluang dan ancaman; maka usaha peningkatan produktivitas kopi robusta berada pada Kuadran 2 (yaitu Mendukung Strategi Diversifikasi). Strategi Diversifikasi lebih difokuskan pada Strategi ST yaitu menggunakan kekuatan untuk menghindari atau meminimalkan ancaman (Gambar 1). Strategi yang ditemukan dalam penelitian ini berbeda dengan hasil penelitian Subekti et al. (2019) tentang strategi pengembangan usahatani kopi di Kabupaten Tojo Una-Una Provinsi Sulawesi Tengah. Penelitian di Desa Tombiano Kecamatan Tojo Barat Kabupaten Tojo Una Una, strategi pengembangan usahatani kopi yang ditemukan berada pada Kuadran 1 . Kondisinya sangat berbeda dengan lokasi penelitian ini, karena di Kecamatan Tojo Barat, Kabupaten Tojo Una Una memiliki kekuatan yang dapat digunakan untuk memanfaatkan peluang yang ada. Dengan demikian, strategi yang diterapkan dalam peningkatan usahatani kopi adalah mendukung Kebijakan Agresif. Strategi agresif ditempuh melalui optimalisasi penggunaan lahan, suplai produksi, dan penggunaan teknologi untuk meningkatkan produksi dan pendapatan petani.

Tabel 3. Bobot dan Rating Faktor Internal

\begin{tabular}{|c|c|c|c|}
\hline Faktor Internal & $\mathrm{R}$ & $\mathrm{B}$ & Skor $(\mathrm{R} \times \mathrm{B})$ \\
\hline Kekuatan: & & & \\
\hline 1. Lahan dan agroklimat sesuai & 4 & 0,20 & 0,80 \\
\hline 2. Pengalaman petani & 3 & 0,10 & 0,30 \\
\hline 3. Varietas tanaman sesuai & 1 & 0,05 & 0,05 \\
\hline 4. Biaya produksi lebih rendah & 2 & 0,10 & 0,20 \\
\hline 5. Manajemen usaha tani lebih mudah & 3 & 0,15 & 0,45 \\
\hline Skor kekuatan & & 0,60 & 1,80 \\
\hline Kelemahan: & & & \\
\hline 1. Kelembagaan petani belum baik & 2 & 0,05 & 0,10 \\
\hline 2. Motivasi petani masih rendah & 1 & 0,10 & 0,10 \\
\hline 3. Peremajaan tanaman kopi & 4 & 0,10 & 0,40 \\
\hline 4. Produktivitas masih rendah & 3 & 0,10 & 0,30 \\
\hline 5. Pemeliharaan tanaman pelindung & 4 & 0,05 & 0,20 \\
\hline Skor kelemahan: & & 0,40 & 1,10 \\
\hline Selisih & & & 0,70 \\
\hline
\end{tabular}


Tabel 4. Bobot dan Rating Faktor Eksternal

\begin{tabular}{|l|c|c|c|}
\hline Faktor Eksternal & $\mathrm{R}$ & $\mathrm{B}$ & Skor (R x B) \\
\hline Peluang: & & & \\
1. Perkembangan lembaga permodalan mikro & 4 & 0,10 & 0,40 \\
2. Permintaan kopi robusta tingkat lokal & 2 & 0,10 & 0,20 \\
3. Pasar domestik dan ekspor terbuka & 3 & 0,15 & 0,45 \\
4. Bibit kopi berkualitas tersedia & 1 & 0,05 & 0,05 \\
5. Kebijakan pemerintah daerah & 1 & 0,05 & 0,05 \\
\hline Skor peluang: & & 0,45 & 1,15 \\
\hline Ancaman: & & & \\
1. Konversi ketanaman kopi arabika & 2 & 0,10 & 0,20 \\
2. Fluktuasi harga jual di tingkat petani & 4 & 0,20 & 0,80 \\
3. Konversi ke tanaman jeruk dan tanaman lainnya & 1 & 0,05 & 0,05 \\
4. Kurangnya penyuluhan dan pelatihan & 3 & 0,10 & 0,30 \\
5. Ketersediaan dan harga sarana produksi & 2 & 0,10 & 0,20 \\
\hline Skor ancaman: & & 0,55 & 1,55 \\
\hline Selisih & & & $(0,40)$ \\
\hline
\end{tabular}

Strategi Pengembangan. Alternatif strategi yang dapat ditempuh adalah: Strategi SO: (1) Mengoptimalkan penggunaan lahan dan agroklimat untuk memenuhi permintaan lokal, domestik, dan ekspor dengan fasilitas permodalan mikro (S1, O1, O2, O3); (2) Meningkatkan penggunaan bibit berkualitas yang sesuai dengan kondisi lokal berbasis pengalaman usahatani yang dimiliki petani (S2, S2, O4); dan (3) Meningkatkan produksi dengan perbaikan manajemen usahatani dan fasilitasi program pengembangan dari pemerintah daerah (S4, S5, O5).

Strategi ST: (1) Optimalisasi penggunaan lahan dan varietas yang sesuai untuk meminimalkan konversi ke tanaman kopi arabika dan tanaman lainnya (S1, S3, T1, T3); (2) Mendayagunakan pengalaman petani dan kemudahan manajemen usahatani dalam menyikapi kurangnya penyuluhan dan pelatihan yang tersedia (S2, S5, T4); (3) Memanfaatkan bahanbahan lokal sebagai sarana produksi berbasis pengalaman, biaya murah, dan manajemen usahatani yang fleksibel ( $\mathrm{S} 2$, S4, S5, T5); dan (4) Memadukan kekuatan internal untuk meningkatkan kualitas produk untuk meningkatkan posisi tawar (S1-S5, T2).

Strategi yang dihasilkan dalam penelitian ini didukung hasil penelitian Abimanyu et al. (2018) yang menyatakan bahwa pupuk anorganik, pupuk organik, dan pengalaman petani berpengaruh nyata 113 dalam meningkatkan produksi kopi robusta di Kecamatan Panti Kabupaten Jember. Hal senada dikemukakan oleh Ariyanti et al. (2019) yang menyatakan bahwa strategi pengembangan agribisnis kopi robusta di Kabupaten Tanggamus dilakukan melalui ekspansi lahan, penerapan penanaman bibit unggul dan melakukan replanting.

Strategi WO: (1) Meningkatan peran pemerintah daerah untuk revitalisasi kelembagaan petani dan menggugah motivasi petani sebagai bagian dari stakeholder kopi nasional (O5, W1, W2); (2) Meningkatkan kerjasama dengan lembaga permodalan dan penyedia bibit berkualitas untuk peremajaan tanaman, pemeliharaan tanaman pelindung, dan peningkatan produkstivitas (O1, O4, W3, W4, W5); dan (3) Meningkatkan motivasi petani untuk meningkatkan produktivitas berdasarkan informasi peningkatan permintaan lokal, domestik, dan ekspor kopi robusta $(\mathrm{O} 2, \mathrm{O} 3, \mathrm{~W} 2, \mathrm{~W} 4)$.

Strategi WT: (1) Revitalisasi kelembagaan petani dan meningkatkan motivasi petani untuk meminimalkan pengaruh minimnya penyuluhan dan kelangkaan sarana produksi (W1, W2, T4, T5); (2) Kegiatan peremajaan tanaman dan peningkatan produktivitas untuk meminimalkan konversi tanaman (W3, W4, T1, T3); dan (3) Meningkatan kualitas produk untuk meminimalkan fluktuasi harga melalui peningkatan posisi tawar petani (W5, T2). 


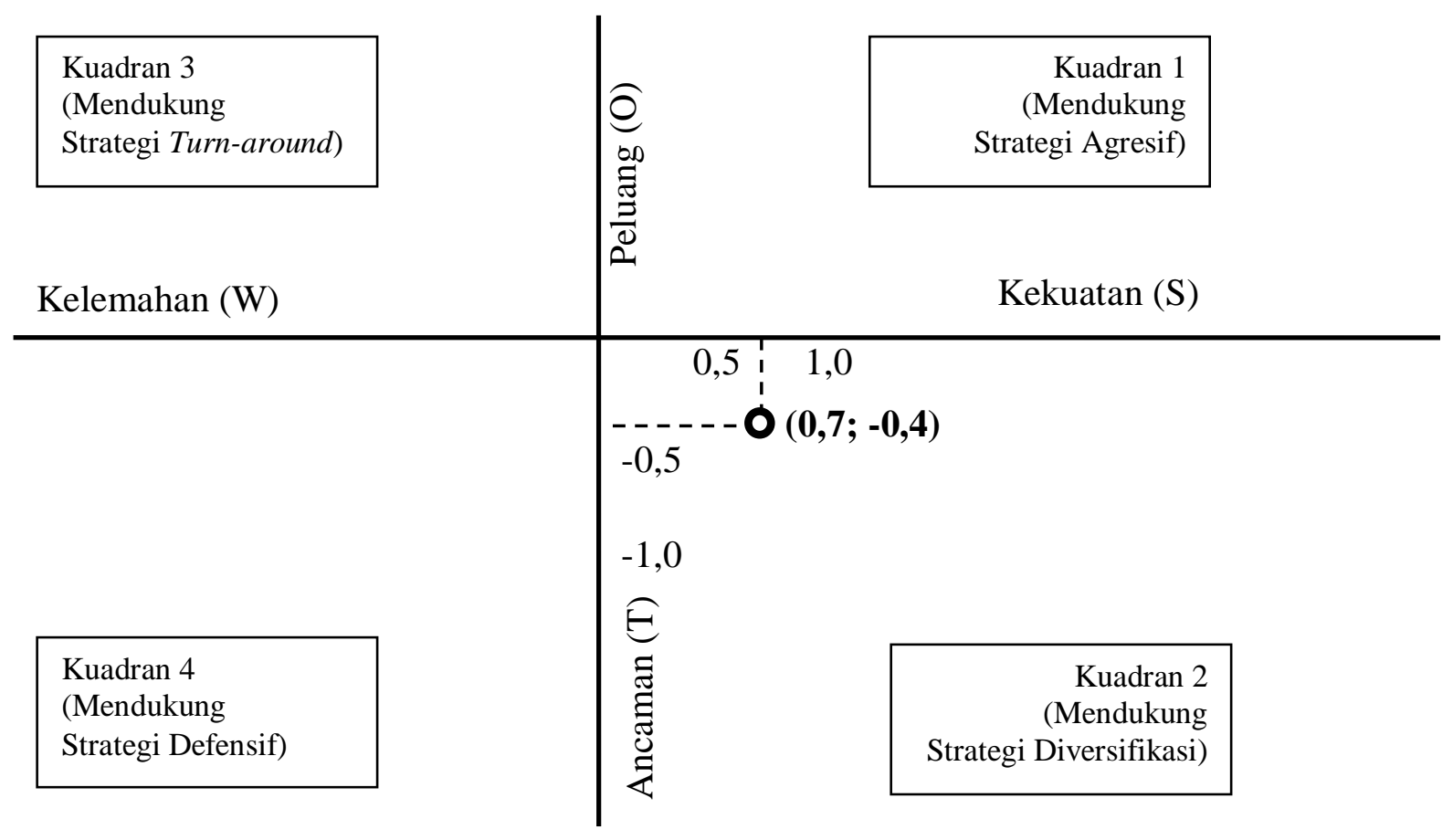

Gambar 1. Diagram Cartesius Analisis SWOT

Tabel 5. Matriks SWOT Strategi Peningkatan Produktivitas Kopi Robusta

\begin{tabular}{|c|c|c|}
\hline Faktor Eksternal Faktor Internal & $\begin{array}{l}\text { 1) Kekuatan (S): } \\
\text { 1. Lahan dan agroklimat sesuai. } \\
\text { 2. Pengalaman petani. } \\
\text { 3. Varietas tanaman sesuai. } \\
\text { 4. Biaya produksi lebih rendah. } \\
\text { 5. Manajemen usahatani lebih mudah. }\end{array}$ & $\begin{array}{l}\text { 2) Kelemahan (W): } \\
\text { 1. Kelembagaan petani belum baik. } \\
\text { 2. Motivasi petani masih rendah. } \\
\text { 3. Peremajaan tanaman kopi. } \\
\text { 4. Produktivitas masih rendah. } \\
\text { 5. Pemeliharaan tanaman pelindung. }\end{array}$ \\
\hline $\begin{array}{l}\text { 3) Peluang }(\mathrm{O}) \text { : } \\
\text { 1. Perkembangan lembaga } \\
\text { permodalan mikro } \\
\text { 2. Permintaan kopi robusta } \\
\text { tingkat lokal } \\
\text { 3. Pasar domestik dan ekspor } \\
\text { terbuka } \\
\text { 4. Bibit kopi berkualitas } \\
\text { tersedia } \\
\text { 5. Kebijakan pemerintah } \\
\text { daerah }\end{array}$ & $\begin{array}{l}\text { 4) Strategi SO: } \\
\text { 1. Mengoptimalkan penggunaan lahan dan } \\
\text { agroklimat untuk memenuhi permintaan } \\
\text { lokal, domestik, dan ekspor dengan fasilitas } \\
\text { permodalan mikro. (S1, O1, O2, O3) } \\
\text { 2. Meningkatkan penggunaan bibit berkualitas } \\
\text { yang sesuai dengan kondisi lokal berbasis } \\
\text { pengalaman usahatani yang dimiliki petani. } \\
\text { (S2, S2, O4) } \\
\text { 3. Meningkatkan produksi dengan perbaikan } \\
\text { manajemen usahatani dan fasilitasi program } \\
\text { pengembangan dari pemerintah daerah. (S4, } \\
\text { S5, O5) }\end{array}$ & $\begin{array}{l}\text { 5) Strategi WO: } \\
\text { 1. Meningkatan peran pemerintah daerah untuk } \\
\text { revitalisasi kelembagaan petani dan } \\
\text { menggugah motivasi petani sebagai bagian } \\
\text { dari stakeholder kopi nasional. (O5, W1, W2) } \\
\text { 2. Meningkatkan kerjasama dengan lembaga } \\
\text { permodalan dan penyedia bibit berkualitas } \\
\text { untuk peremajaan tanaman, pemeliharaan } \\
\text { tanaman pelindung, dan peningkatan } \\
\text { produktivitas. (O1, O4, W3, W4, W5) } \\
\text { 3. Meningkatkan motivasi petani untuk } \\
\text { meningkatkan produktivitas berdasarkan } \\
\text { informasi peningkatan permintaan lokal, } \\
\text { domestik, dan ekspor kopi robusta. (O2, O3, } \\
\text { W2, W4) }\end{array}$ \\
\hline $\begin{array}{l}\text { 6) Ancaman (T) } \\
\text { 1. Konversi ketanaman kopi } \\
\text { arabika } \\
\text { 2. Fluktuasi harga jual di } \\
\text { tingkat petani } \\
\text { 3. Konversi ke tanaman jeruk } \\
\text { dan tanaman lainnya } \\
\text { 4. Kurangnya penyuluhan } \\
\text { dan pelatihan } \\
\text { 5. Ketersediaan dan harga } \\
\text { sarana produksi }\end{array}$ & $\begin{array}{l}\text { 7) Strategi ST: } \\
\text { 1. Optimalisasi penggunaan lahan dan varietas } \\
\text { yang sesuai untuk meminimalkan konversi } \\
\text { ke tanaman kopi arabika dan tanaman } \\
\text { lainnya. (S1, S3, T1, T3) } \\
\text { 2. Mendayagunakan pengalaman petani dan } \\
\text { kemudahan manajemen usahatani dalam } \\
\text { menyikapi kurangnya penyuluhan dan } \\
\text { pelatihan yang tersedia. (S2, S5, T4) } \\
\text { 3. Memanfaatkan bahan-bahan lokal sebagai } \\
\text { sarana produksi berbasis pengalaman, biaya } \\
\text { murah, dan manajemen usahatni yang } \\
\text { fleksibel. (S2, S4, S5, T5). } \\
\text { Memadukan kekuatan internal untuk } \\
\text { meningkatkan kualitas produk untuk } \\
\text { meningkatkan posisi tawar dalam harga jual. } \\
\text { (S1-S5, T2) }\end{array}$ & $\begin{array}{l}\text { 8) Strategi WT: } \\
\text { 1. Revitalisasi kelembagaan petani dan } \\
\text { meningkatkan motivasi petani untuk } \\
\text { meminimalkan pengaruh minimnya } \\
\text { penyuluhan dan kelangkaan sarana produksi. } \\
\text { (W1, W2, T4, T5) } \\
\text { 2. Kegiatan peremajaan tanaman dan peningkatan } \\
\text { produktivitas untuk meminimalkan konversi } \\
\text { tanaman. (W3, W4, T1, T3) } \\
\text { 3. Meningkatan kualitas produk untuk } \\
\text { meminimalkan fluktuasi harga melalui } \\
\text { peningkatan posisi tawar petani. (W5, T2) }\end{array}$ \\
\hline
\end{tabular}




\section{KESIMPULAN DAN SARAN}

Produktivitas tanaman kopi robusta di daerah penelitian adalah 1,275 ton/ha/tahun, dengan nilai R/C sebesar 2,67. Strategi peningkatan produktivitas usahatani kopi robusta berada pada Kuadran 2 (Strategi Diversifikasi). Strategi yang sesuai untuk digunakan adalah Strategi ST melalui: (1) Penggunaan lahan dan varietas yang sesuai untuk meminimalkan konversi ke tanaman kopi arabika dan tanaman lainnya; (2) Mendayagunakan pengalaman petani dan kemudahan manajemen usahatani dalam menyikapi kurangnya penyuluhan dan pelatihan yang tersedia; (3) Memanfaatkan bahan-bahan lokal sebagai sarana produksi berbasis pengalaman, biaya murah, dan manajemen usahatani yang fleksibel; dan (4) Memadukan kekuatan internal untuk meningkatkan kualitas produk untuk meningkatkan posisi tawar dalam harga jual.

Pemerintah daerah melalui dinas teknis terkait disarankan untuk lebih fokus memberikan pelayanan yang baik melalui kegiatan pelatihan dan penyuluhan teknis untuk memperbaiki manajemen usahatani kopi robusta di daerah penelitian ini.

\section{DAFTAR PUSTAKA}

Abman, R., Carney, C., 2020. Agricultural productivity and deforestation: Evidence from input subsidies and ethnic favoritism in Malawi. Journal of Environmental Economics and Management 103, 102342. https://doi.org/10.1016/j.jeem.2020.10 $\underline{2342}$

Abimanyu, W., Hadi, S., dan Ridho, A. A., 2018. Studi Komparatif Usaha Perkebuna Kopi Robusta dan Kopi Arabika di Kecamatan Panti Kabupaten Jember, Jurnal Agribest 2 (1): 14-23.

Aklimawati, L., Yusianto, dan Mawardi, S. (2014). Karakteristik Mutu dan
Agribisnis Kopi Robusta di Lereng Gunung Tambora, Sumbawa. Pelita Perkebunan 30 (2), 159-180.

Amsalu, A. and Ludi. E., 2010. The Effect of Global Coffee Price Changes on Rural Livelihoods and Natural Resource Management in Ethiopia: A case study from Jimma Area, NCCR North-South Dialogue No. 26.

Ariyanti, W., Suryantini, A., dan Jamhari, 2019. Usahatani Kopi Robusta di Kabupaten Tanggamus: Kajian Strategi Pengembangan Agrobisnis, Jurnal Kawistara 9 (2): 179-191.

Badan Pusat Statistik Kabupaten Simalungun, 2005. Simalungun Dalam Angka 2015, Badan Pusat Statistik Kabupaten Simalungun.

Batista, M.J.P.A., Ávila, A.F., Franca, A.S., Oliveira, L.S., 2020. Polysacchariderich fraction of spent coffee grounds as promising biomaterial for films fabrication. Carbohydrate Polymers 233, 115851. https://doi.org/10.1016/j.carbpol.2020. $\underline{115851}$

Direktorat Jenderal Perkebunan, 2017. Statistik Perkebunan Indonesia 2016-2018: Kopi. Ditjenbun Kementerian Pertanian RI.

http://ditjenbun.pertanian.go.id/?publik asi=buku-publikasi-statistik-2016-2018 (diakses 25 April 2020).

Glueck, W. F., dan Jauch, L. R., 1994. Manajemen Strategis dan Kebijakan Perusahaan, Erlangga, Jakarta.

Gong, B., 2020. Agricultural productivity convergence in China. China Economic Review 60, 101423. https://doi.org/10.1016/j.chieco.2020.1 $\underline{01423}$

Gregory, A. and Featherstone, A. M., 2008. Nonparametric Efficiency Analysis for Coffee Farms in Puerto Rico, Selected paper prepared for presentation at the 
Southern Agricultural Economics Association Annual Meeting, Dallas.

Habibi, Darman, S., dan Damayanti, L., 2019. Strategi Pengembangan Usahatani Nilam di Kecamatan Batudaka Kabupaten Tojo Una-Una, J. Agroland 26 (3): 212-220.

Heryanto, dan Ramadhoni, E., 2018. Marketing Strategy for Rahn Products and Transactions at an Indonesian Bank, Expert Journal of Marketing 6 (2): 52-64.

International Coffee Organization (ICO), 2010. The Story of Coffee. http://www.ico.org/coffee_story.asp [diakses 23 Februari 2020]

INTERNATIONAL COFFEE ORGANIZATION (ICO), 2019. HISTORICAL DATA ON THE GLOBAL COFFEE TRADE, HTTP://WWW.ICO.ORG/NEW_HISTORIC AL.ASP (DIAKSES 25 APRIL 2020).

Kapri, K., Ghimire, S., 2020. Migration, remittance, and agricultural productivity: Evidence from the Nepal Living Standard Survey. World Development Perspectives 100198. https://doi.org/10.1016/j.wdp.2020.100 $\underline{198}$

Laili, E. F. Dan Diartho, H.C., 2018. Pengembangan Kawasan Pertanian Berbasis Tanaman Pangan di Kecamatan Wuluhan, kabupaten Jember, Journal of Regional and Rural Development Planning 2 (3): 209-217.

Listyati, D., Sudjarmoko, B., Hasibuan, A. M., dan Randriani, E., 2017. Analisis Usahatani dan Rantai Tata Niaga Kopi Robusta di Bengkulu, Jurnal Tanaman Industri dan Penyegar 4 (3): 145-154.

Mahfud, M. C., Nurbanah, S., Ismiyati, dan Ardiansyah, 2010. Kajian Penerapan Teknologi Produksi pada Usahatani Kopi Robusta di Lokasi Prima Tani Kabupaten Pasuruan, Jurnal Pengkajian dan Pengembangan Teknologi Pertanian 13 (2): 141-147.
Murdani, dan Koswara, A., 2018. Analisis Pengembangan Kelembagaan Gapoktan Mulyajaya (Studi Kasus di Desa Lumbangsari Kecamatan Bululawang Kabupaten Malang Jawa Timur, Jurnal Pendidikan Nonformal 13 (1): 10-20.

Mintzberg, H., and Quinn, J. B., 1991. The Strategy Process, Contexts, and Class, Practice Hall International Inc.

Naegele, H., 2020. Where does the Fair Trade money go? How much consumers pay extra for Fair Trade coffee and how this value is split along the value chain. World Development 133, 105006. https://doi.org/10.1016/j.worlddev.202 $\underline{0.105006}$

Quezada, L.E., Reinao, E.A., Palominos, P.I., Oddershede, A.M., 2019. Measuring Performance Using SWOT Analysis and Balanced Scorecard. Procedia Manufacturing 39, 786-793. https://doi.org/10.1016/j.promfg.2020. $\underline{01.430}$

Rivera-Padilla, A., 2020. Crop choice, trade costs, and agricultural productivity. Journal of Development Economics 146 , 102517. https://doi.org/10.1016/j.jdeveco.2020. $\underline{102517}$

Saragih, J. R., 2018. Strategi Pengembangan Agribisnis Hortikultura di Wilayah Pedesaan, Talenta Conference Series 1(1): 62-69, Talenta Publisher Universitas Sumatera Utara.

Shen, Z., Baležentis, T., Ferrier, G.D., 2019. Agricultural productivity evolution in China: A generalized decomposition of the Luenberger-Hicks-Moorsteen productivity indicator. China Economic Review 57, 101315. https://doi.org/10.1016/j.chieco.2019.1 $\underline{01315}$

Subekti, A., Rauf, R. A., dan Damayanti, L., 2019. Strategi Pengembangan Usahatani Kopi di Desa Tombiano Kecamatan Tojo Barat Kabupaten Tojo Una-Una, J. Agroland 26 (3): 230-240. 
Sunanto, Salim, dan Rauf, A. W., 2019. Analisis Kesepakatan Peningkatan Produktivitas Kopi Arabika pada Pengembangan Kawasan di Kabupaten Toraja Utara, Jurnal Sosial Ekonomi Pertanian 15 (1): 42-55.
Thamrin, H., Pamungkas, E.W., 2017. A Rule Based SWOT Analysis Application: A Case Study for Indonesian Higher Education Institution. Procedia Computer Science 116, 144-150. https://doi.org/10.1016/j.procs.2017.10 .056 